\title{
THE VETO AND THE CHARTER: AN INTERPRETATION FOR SURVIVAL
}

\author{
MYRES S. MCDOUGAL $\uparrow$ AND RICHARD N. GARDNER*
}

\author{
Scire leges non hoc est verba earum tenere, \\ sed vim ac potestatem. \\ -Celsus, Dig. I, 3, 17.
}

WhEN the United Nations Security Council in late June, 1950, condemned the armed attack upon the Republic of South Korea as a breach of the peace and called upon member nations to help repel the invaders, an important new landmark was established in world politics. For the first time in history, a world organization had launched a campaign of collective action to put down aggression and establish peace under international law. This action of the Security Council, approved and supported by the overwhelming majority of the United Nations, gave the peoples of the world hope, above all else, that their organization would survive and contribute to the major purpose for which it was established- "to save succeeding generations from the scourge of war." 1

Rarely has an act of aggression been so clear-cut or the issues so welldefined. These issues can be best understood in the light of events in Korea following the surrender of Japan. The Soviet Union consistently refused to implement joint agreements for the establishment of a unified and independent Korea. Instead, it treated the boundary at the 38th parallel, which was adopted for surrender purposes only, as a permanent division of the country and worked to establish exclusive control in the Northern zone. The United States, finding agreement impossible, put the problem of Korea before the United Nations. A United Nations Commission, established to hold free elections throughout the country, was never permitted to enter North Korea. Nevertheless, elections under its authority were held in the South. They produced a government which was found by the General Assembly to represent the free will of the electorate and which was designated the only lawfully existing government in Korea. ${ }^{2}$ Then, on June 25, 1950, without warning and without provocation, the forces of North Korea launched an offensive which subsequent events have confirmed as a "premeditated, well-prepared, and well-timed plan of aggression." 3

$\dagger$ William K. Townsend Professor of Law, Yale Law School.

* Note Editor, Yale Law Journal.

1. U. N. Charter, Preamble.

2. Gen. Assembly Res. 195 (III).

3. Report of the United Nations Commission on Korea to the fifth session of the General Assembly, Doc. A/1350, reprinted in summary form in 4 International ORganization 614-5 (1950). See also Departarent of State, United States Policy in 
The attack by North Korea left the United Nations with little alternative. To have ignored this brazen aggression would have meant the abdiction of its responsibility to the people of Korea and of its functions as an instrument of collective security. The unopposed occupation of South Korea might have been the signal for similar acts of aggression throughout Asia and on the continent of Europe. The Security Council had to act swiftly and decisively and that is precisely what it proceeded to do-thanks to the absence of the Soviet delegate who had left some five months earlier in protest over the presence in the Council of Nationalist China. ${ }^{4}$ In an emergency session on June 25, the Council, finding the "armed attack" by North Korea to be a "breach of the peace," called for the cessation of hostilities, the withdrawal of North Korean forces, and the cooperation of all U.N. members in carrying out the resolution. ${ }^{5}$ Two days later, it recommended "that the Members of the United Nations furnish such assistance to the Republic of South Korea as may be necessary to repel the armed attack and to restore international peace and security in the area." 0 These resolutions were supported by 53 member nations. ${ }^{7}$

It would be a sad paradox indeed if the one act which gave the United Nations its greatest hope for survival in fact could be called beyond its competence in law. As might be expected, the validity of the Security Council's resolutions was challenged shortly after their passage by the Soviet Union and its satellites. ${ }^{8}$ Since then, however, several observers

THE Korean CrISIs ix-xi (July, 1950) ; Potter, Legal Aspects of the Situation in Korea, 44 AMr. J. INT'L L. 709 (1950).

4. The Soviet Union left the Council at the 461 st meeting on January 13,1950 . See Security Council, Official Records, 5th year, No. 3, p. 10.

5. U.N. Doc. S/1501. This included a request to members to "refrain from giving assistance to the North Korean authorities."

6. U.N. Doc. S/1511. Two other resolutions concerning Korea were adopted later, also during the absence of the Soviet Union. The third resolution, adopted on July 7, 1950 , recommended that all members providing military forces and other assistance pursuant to the first two resolutions "make such forces and other assistance available to a unified command under the United States" and requested the United States to designate the commander of such forces. U.N. Doc. S/1588. The fourth resolution, adopted on July 31,1950, provided machinery for the "relief and support of the civilian population of Korea." U.N. Doc. S/1657.

7. Messages of United Nations members supporting the resolutions of the Security Council have been collected in Departarent of State, United States Policy in the Korean Crisis 28 et seq. (July, 1950).

8. The Soviet Union directed a cablegram to the Secretary-General of the United Nations on June 29,1950, concerning the Council resolution of June 27. The cablegram declared that one vote had been cast by the "Kuomintang representative" of China and charged that "the above resolution was passed in the absence of two permanent members of the Security Council, the Union of Soviet Socialist Republics and China, whereas under the United Nations Charter a decision of the Security Council on an important matter can only be made with the concurring votes of all five permanent members. . . . In view of the foregoing it is quite clear that the said resolution of the Security Council on the 
whose sincerity and disinterestedness is beyond question have raised a similar challenge. ${ }^{9}$ This challenge requires a convincing and comprehensive answer. The free world has too much at stake to permit any doubts to persist concerning the legal basis of the Korean campaign. Furthermore, the kind of interpretation of the United Nations Charter that yields the conclusion of illegality with respect to the Korean action may be used to yield the same conclusion with respect to current plans for collective action of even greater prospective importance.

The principal attack upon the validity of the Korean resolutions is cast in terms of an attempted literal interpretation of the provisions of the United Nations Charter for voting in the Security Council. ${ }^{10}$ The most comprehensive and detailed elaboration of this attack is that of Professor Leo Gross in his "Voting in the Security Council: Abstention from Voting and Absence from Meetings." 11 Professor Gross makes what he calls an "objective" analysis of Article 27, paragraph 3. This paragraph provides that decisions of the Security Council on all matters other than procedural

"shall be made by an affirmative vote of seven members including the concurring votes of the permanent members."

Rendering the final seven words as if they read "the concurring votes of all five permanent members, who must be present and voting," Professor Gross concludes that since the Soviet Union was absent during the passage of the Korean resolutions and did not cast a concurring vote, the Korean resolutions are invalid. With necessary consistency, he insists further that the validity of all the substantive resolutions passed between January 13, when the Soviet delegate left the Council, and August 20 , when that delegate returned, cannot be explained and that the unavoidable import of Article 27(3) is to permit any one of the five permanent members of the Security Council to render that body impotent by the simple expedient of staying away.

Korean question has no legal force." U.N. Doc. S/1517. The same view was expressed in declarations made by Czechoslovakia, Poland, the Ukrainian Soviet Socialist Republic and the Byelorussian Soviet Socialist Republic. U.N. Docs. S/1523, S/1545, S/1598, $\mathrm{S} / 1600$. The Secretary General also received similar statements from the Korean People's Democratic Republic and the People's Republic of China. U.N. Docs. S/1527 and S/1527/corr.1, S/1554, p. 3; and S/1583.

9. See Gross, Voting in the Security Conncil: Abstention from Voting and Absence from Meetings, 60 Yate L.J. 209 (1951); Schick, Videant Consules, 3 West Por. Q. 311 (1950); and Note, 28 CAN. BAR REv. 902 (1950).

Arguments of the same general tenor have recently been made on the floor of the Senate by Senator Taft. 82nd Cong. 1st Sess. Jan. 5, 1951, 97 CoNG. REc. 58.

10. Other arguments of illegality are so insubstantial as to require no special answer. Most of them are rejected or lightly regarded even by the people who suggest them. See Schick, supra note 9.

11. 60 YALE L.J. 209 (1951). 
These astonishing conclusions Professor Gross justifies largely by reiterated emphasis that the words of Article 27 are "unambiguous" and "mandatory." ${ }^{12}$ There is "scarcely any room for doubt," he asserts, that the concurring votes of all five permanent members are needed to pass a valid resolution. ${ }^{13}$ The numerous resolutions passed throughout the Council's history without the concurring votes of all five permanent members are discounted on the ground that "mere practice" cannot alter the "strict requirements" of the Charter's words. ${ }^{14}$ The practice of abstention is distinguished from absence on the ground that abstention, "although not in conformity with Article $27(3)$," is "tacit agreement," "a manifestation of consent in disguise," and hence not in violation of "the principle of unanimity." 15 Not even the "rule of effectiveness," a principle which gives preference to that interpretation of a treaty which best promotes its major purposes, can justify a broader interpretation. ${ }^{16}$ Paralysis in the event of the absence of great power agreement was the "intended" result of the Yalta voting formula. "The Council was infected," so we are told, "with the virus of paralysis at its birth." 18 It makes no difference that the absence of the Soviet Union was voluntary-an attempt to intimidate the Council after the failure to oust the representative of Nationalist China. For the provision of Article 27(3) "embodies the principle of unanimity of the permanent members of the Security Council" and is "not concerned with the means or circumstances which prevent the fulfillment of this requirement." ${ }^{19}$ In short, urges Professor Gross, the framers of the Charter made the "error" of assuming unanimity among the great powers, and, since that unanimity has not been forthcoming, the members of the United Nations should accept the fact that their organization "can not function as an effective organ for the maintenance of international peace and security." 20

12. Id. at 224,247 and 249 .

13. Id. at 210. Compare Note, 28 CAN. BAR REv. 902, 906 (1950): "The language used in Article 27 of the Charter leaves no room for doubt as to the intention of the draftsmen."

14. Gross, supra note 9 , at 227.

15. Id. at 253 .

16. Id. at $250-1$.

17. Id. at 254 .

18. Ibid.

19. Ibid.

20. Id. at 251. Compare Schick, stipra note 9, at 322: "The Charter assumes that the five major powers can collaborate for peace, and it recognizes the truism that without the collaboration of all five powers there cannot be in fact collective action by the community of nations. . . . Consequently, there is an unfortunate air of disingenuousness about arguments concerning voting whose substantive purport is the pretense that the Soviet Union is a party to the coercive action of the United Nations against North Korea, a 


\section{The Fallacy of the "Unambiguous Meaning"}

The most obvious of several fatal defects in this attack upon the legality of the Korean resolutions is the assumption that the words of Article 27(3) have an "unambiguous" meaning which makes their interpretation unnecessary. In its most vulnerable form, this assumption seems to be that the words have an "absolute" meaning, independent of their users and interpreters, and independent of objectives and contexts. ${ }^{21}$ It is no longer revolutionary, however, to point out that the effort to impose upon any legal language-especially upon language of a complicated multilateral treaty like the United Nations Charter-an "absolute," "literal," "plain," or "natural" meaning puts an impossible burden on words. ${ }^{22}$ "The view that the verbal expression of a legal norm has only one 'true' meaning which can be discovered by correct interpretation," Professor Kelsen writes, "is a fiction, adopted to maintain the illusion of legal security, to make the law-seeking public believe that there is only one possible answer to the question of law in a concrete case." ${ }^{23}$ The main point was long ago generalized by Dean Wigmore:

pretense which every newspaper reader knows to be untrue. Perhaps the United States would stand better in world opinion if the action in Korea were candidly justified on the same ground as the companion actions with regard to Formosa and Indo-China."

21. This may be called the fallacy of univocalism, the fallacy that words speak for themselves and with a single voice.

In the pages that follow it is our purpose to expose this assumption of "unambiguous meaning", and to propose a more rational principle of interpretation, both in general and in specific application to article $27(3)$.

22. For excellent exposition see $\mathrm{Yu}$, The Interpretation of Treaties 44 et seq. (1927). Hudson, The Pernianent Court of International Justice 641 (1943), writes, "Few terms of art may be said to exist in international law, and as the terms employed in international instruments seldom have an exact meaning, they can be interpreted only by giving content to them. This is not a matter of mechanical operation; it is not a process which performs itself automatically; results have to be kept in mind, judgment must be exercised, many factors must be appreciated."

Compare on statutory interpretation CoHEN, LAw AND THE SOCIAL ORdER 130-1 (1933) : "What is the meaning of a statute? The rule that courts must interpret the meaning of the statute rather than the intention of the legislature is frequently conceived as if it implied that the words of a statute are sufficient to determine every question that arises under it. This would lead to a revival of the stage of strict law in which the strictly literal meaning of words is followed no matter how unjust or absurd the consequences. Doubtless there are many who still believe juristic interpretation to be a kind of magic whereby a whole body of law is made to spring out of a few words or phrases. But most modern jurists are outgrowing the superstitious aura of the printed word and its magic potency. The meaning of a statute consists in the system of social consequences to which it leads or of the solutions to all the possible social questions that can arise under it. These solutions or systems of consequences cannot be determined solely from the words used, but require a knowledge of the social conditions to which the law is to be applied as well as of the circumstances which led to its enactment. Legal rules relate to human life, and grammar and logic alone will not enable us to deduce their juridical consequences."

23. Kelsen, The LaW of the UNited Nations xiv (1950). 
"There can be, in the nature of things, no absoluteness of standard in interpretation. . . . The fallacy consists in assuming that there is or ever can be some one real or absolute meaning. In truth, there can be only some person's meaning. . . ." 24

To this succinct statement, Dean Wigmore might well have added: not only "some person's meaning," but some person's meaning in relevant context. It is the principal lesson of contemporary semantics that all words, legal and otherwise, take their complete meaning from such a context. ${ }^{25}$ For understanding any communication the relevant and indispensable questions are: Who, says What, to Whom, for what Objectives, How, under what Conditions, and with what Effects. ${ }^{26}$ Omission of any element of this inquiry leaves an observer in that degree with inadequate or false orientation. It should need no further emphasis today that the words of an international agreement cannot be taken as timeless absolutes; ${ }^{27}$ apart from their uses in context, such words, like other words, are but "shapes on paper" or "agitations in the air." 28 This common sense insight, long accepted with respect to national constitutions and authoritative doctrine, ${ }^{29}$ is made fully explicit with respect to treaties by the Harvard Research:

"[T]he bare words of a treaty have significance only as they may be taken as expressions of the purpose or design of the parties which employed them; they have a 'meaning' only as they are considered in the light of the whole setting in which they are employed. To purport to attribute a 'clear,' a 'natural,' or a pre-existing meaning to them apart from that setting is to ignore the fact that words may be given any meaning which the parties using them may agree to give them, and that few words have an exact and single meaning. 'Such is the inevitable imperfection and ambiguity of all human language, that the mere words alone of any writing, lit-

24. 9 WIGMORE, Evidence 191-2 (3d ed. 1940).

25. For full exposition see Morris, Signs, Language and Behavior (1946); Sapir, Language, 9 Encyc. Soc. ScI. 169 (1933); Richards, The PhIlosophy of Rhetoric (1936) ; Lasswell, Power and Personality 217 et seq. (1948) ; Philbruck, Language AND THE LAW C. 2 (1950).

26. Lasswell, The Structure and Function of Communication in Society in BRYson, The Cominunication of Ideas (1948).

27. See, e.g., the words of Schachter, Deputy Legal Advisor of the U.N., in his superb review of KELSEN, LAw OF THE UNITED NATIONS: "There are certainly no logical reasons why the admittedly vague and imprecise language of the Charter must be restricted in meaning. The Charter is surely not to be construed like a lease of land or an insurance policy ; it is a constitutional document whose broad phrases were designed to meet changing circumstances for an undefined future." 60 Y ALE L.J. 189 (1951).

28. The quoted words are borrowed from I. A. Richards.

29. For discussion and citations, see McDougal \& Lans, Treaties and CongressionalExecutive or Presidential Agreements: Interchangeable Instruments of National Policy, 54 Y YLE L.J. 181, 212 (1945). A fuller exposition appears in Llewellyn, The Constitum fion as an Institution, 34 CoL. L. REv. 1 (1934). 
erally expounded, will go a very little way towards explaining its meaning." " 30

An observer who seeks to cloak his interpretation in some fanciful depersonalized, disembodied "literal" meaning which transcends context merely conceals from himself, and perhaps from others, his own active role, and the context he substitutes, in the choices he makes. The alleged canon that "it is not allowable to interpret what has no need of interpretation" or as otherwise stated, that "one cannot disturb a plain meaning," is little more than a myopic platitude which serves to maintain a primitive and irrational faith in the omnipotence of words. ${ }^{31}$

A second, and only less vulnerable, form of the assumption of "unambiguous meaning" is that it is possible for contemporary interpreters to divine in detail the "true" or "real" intention of agreement makers of an earlier day. ${ }^{32}$ When an agreement of any importance is effected among two or more nation-states the relevant events include, at the minimum: a great variety of actors (negotiators, drafters, approvers, ratifiers), expressing agreement through verbal forms of all degrees of generality or precision, by all the methods known to international law, for implementation of a great variety of both short-run and longterm objectives, under the peculiar conditions and perspectives of their day, and with certain designed and undesigned effects upon the expectations of all the parties and the distribution of values among them. ${ }^{33}$ When at some later date decision-makers are confronted with the necessity of interpreting this agreement, the events relevant for understanding again include at a minimum: certain interpreters (located in value and institutional position), applying traditional criteria of interpretation, to the words and acts of the earlier day and to the subsequent practice of the parties under the agreement, for certain contemporary objectives, under the conditions and perspectives of

30. Harvard Research Draft on Treaties 947 (1935). The last sentence is quoted from WhEATON, INTERAATTONAL LAW 365 (8th ed. 1866).

31. At least as old as Vattel, this "canon" is now generally recognized to be more misleading than helpful. See, e.g., Yu, op. cit. supra note 22 , at 46,74 , and the vigorous dissection in 9 Wigmore, EvIDENCE 180 (3d ed. 1940): "The process of interpretation ... though it is commonly simple and often unobserved, is always present, being inherently indispensable."

For some of the psychological foundations of faith in the omnipotence of words, see Fenichel, The Psychoanalytical Theory of Neurosis 46, 296, 313 (1945).

32. This may be called the fallacy of "detailism", the fallacy that parties can project a minutely detailed intent into the future and that such intent should prevail over their more general objectives.

33. Some sense of the range of facts involved may be gleaned from HARVARD REsearch, op. cit. supra note 30, or from MCNaIR, The Law of Treaties (1938). An attempt to itemize steps in the process of agreement making appears in McDougal and Lans, supra note 29, at 202. 
their day, and with certain obvious effects upon the distribution of values among the parties. ${ }^{34}$ From this comprehensive perspective of the relevant events, it is wholly fantastic to assume either, first, that the framers of the original agreement can project their vision and anticipate all the more specific details of the evolving future or agree upon a common purpose with respect to all these details or draft so precisely as to remove all ambiguity with respect to such common purpose, or, secondly, that the later interpreters of the agreement working in a new total context, with their own contemporary objectives and conscious of many changes in conditions since the making of the agreement, can resurrect in detail the subjectivities of the original framers of the agreement and ascertain what was their clear intent concerning the new events confronting the interpreter. ${ }^{35}$ For an excellent statement of the general point in more traditional language we turn again to the Harvard Research:

"The process of interpretation, rightly conceived, cannot be regarded as a mere mechanical one of drawing inevitable meanings from the words in a text, or of searching for and discovering some preexisting specific intention of the parties with respect to every situation arising under a treaty. It is precisely because the words used in an instrument rarely have exact and single meanings, and because all possible situations which may arise under it cannot be, or at least are not, forseen and expressly provided for by the parties at the time of its drafting that the necessity for interpretation oc-

34. A glance at the commentary in HARVARD RESEARCH, op. cit. supra note 30 , on Article 19, Interpretation of Treaties, may give an appropriate sense of this process.

35. Hudson, op. cit. supra note 22, at 644, writes: "In litigation, the simple case is relatively rare in which the parties may be said to have foreseen and endeavored to effect a solution of the precise problem presented. The parties seldom proclaim their intention in unmistakable terms; and even if an intention is proclaimed, it must be found to have been expressed in the text. More often, the problem raised before the Court was not foreseen when the instrument in question was being drafted, neither the particular problem nor the general class to which it belongs; or if it was foreseen its solution was not definitely agreed upon. The compromises which are inevitable in framing an international instrument frequently result in the acceptance of a 'formula' which is possible only because it does not foreclose the contentions of any party. No great experience in international conferences is required to know that terms are sometimes employed in treaties of which no common understanding is reached in advance. In some situations, a lack of clarity may even be a desideratum; the chief desire may be to continue uncertainty."

Compare Llewellyn, supra note 29 , at 3 , on the interpretation of the United States Constitution: "There is the notion that the primary source of information as to what our Constitution comes to is the language of a certain document of $1789 .$. . . Is this not extraordinary? The document was framed to start a government experiment for an agricultural, sectional, seaboard folk of some three millions. Yet it is supposed to . . . give basic information about the government of a nation, a hundred and thirty millions strong, whose population and advanced industrial civilization have spread across a continent." 
curs. In most instances therefore, interpretation involves giving a meaning to a text." 36

It is for these reasons, therefore, that each generation must, whatever its preference, in considerable measure interpret its legacy of agreements, as well as of other authoritative doctrine, in terms of contemporary conditions and objectives. Interpreters differ most strikingly only in the degree to which they are conscious of this necessity.

\section{Interpretation by Major Purposes: The Rational Alternative}

It is not intended, however, by this analysis to suggest that concern for the "intent" of framers of agreements is in all measure irrational or that contemporary interpreters can reasonably or legally remake or unmake agreements at their arbitrary pleasure. On the contrary, our concern is, like that of most commentators today, to clarify a mode of interpretation which can give the most rational effect to the intent of framers in so far as they can achieve a common intent and express it. Though it is beyond the competence of framers of agreements to anticipate in utmost detail the unfolding events of the future or to specify with exact precision the minute modalities of their projected cooperation with respect to events and conditions constantly changing, it is possible for them to project both a primary pattern of expectations with respect to their major general objectives, and, with varying degrees of precision, even a secondary pattern of the institutional means by which their objectives are to be effected. When the march of events inevitably lays bare ambiguities and alternatives of interpretation with respect to the secondary institutional means so prescribed, even the most modest deference to rationality must require that interpretation of such means which best promotes the major purposes for which they were established. ${ }^{37}$ Hence the principle of interpretation most

36. Hartard Research Draft on Treaties 946 (1935). See also Hudson, The Pernianent Court of International Justice 1920-42, 641 (1943).

37. This may be called the principle of interpretation by basic goals, which emphasizes the parties' major demands and major expectations, as contrasted with "detailism" which seeks to emphasize lesser demands and more minute expectations.

One of the most frequently quoted statements of the need for this type of interpretation is that of Judge Anzilotti: "[I] do not see how it is possible to say that an article of a convention is clear until the subject and aim of the convention have been ascertained, for the article only assumes its true import in this convention and in relation thereto. Only when it is known what the Contracting Parties intended to do and the aim they had in view is it possible to say either that the natural meaning of terms used in a particular article corresponds with the real intention of the Parties, or that the natural meaning of the terms used falls short of or goes further than such intention." Dissenting opinion in Interpretation of the Convention of 1919 concerning Employment of Women during the Night, P.C.I.J., Ser. A/B, No. 50 (1932).

With respect to domestic constitutional law, Mr. Justice Stone offered excellent formulation of the principle: "If we remember that 'it is a constitution we are expounding,' 
widely supported by disinterested authorities today is that international agreements must be interpreted primarily in terms of the major, general purposes they are intended to serve. ${ }^{38}$ Thus, the Harvard Research, after insisting that the process of interpretation rightly conceived requires the giving, and not simply the finding, or a meaning ${ }^{39}$ continues that the meaning to be given is "not just any meaning which appeals to the interpreter to be sure, but a meaning which, in the light of the test under consideration and of all the concomitant circumstances of the particular case at hand, appears in his considered judgment to be the one that is logical, reasonable, and most likely to accord with and to effectuate the larger general purpose which the parties desired the treaty to serve." 40 In the blackletter of its proposed Draft Convention on the Law of Treaties, the Research is concise, comprehensive, and definitive:

"A treaty is to be interpreted in the light of the general purpose which it is intended to serve. The historical background of the treaty, travaux préparatoires, the circumstances of the parties at the time the treaty was entered into, the change in these circumstances sought to be effected, the subsequent conduct of the parties in applying the provisions of the treaty, and the conditions prevailing at the time interpretation is being made, are to be considered in connection with the general purpose which the treaty is intended to serve." 41

In one form of statement or another, this principle is both of the most ancient lineage ${ }^{42}$ and, as indicated, is today accepted and honored by

we cannot rightly prefer, of the possible meanings of its words, that which will defeat rather than effectuate the constitutional purpose. ... [W] turn to the words of the constitution read in their historical setting as revealing the purpose of its framers, and in search for admissible meanings of its words which, in the circumstances of their application, will effectuate those purposes. ... Words, especially those of a constitution, are not to be read with stultifying narrowness." (and cases cited). United States v. Classic, 313 U.S. 299, 316, 320 (1941).

38. In addition to the authorities collected in the HARVARD RESEARCH, op. cit. sippra note 30, at 948 et seq., see Yu, op. cit. supra note 22, for a thorough and persuasive presentation of the general point of view. Other helpful general references are $2 \mathrm{HYDE}$, INTERNaTional Law 1468 et seq. (2d ed., 1945) ; Fairman, The Interpretation of Treaties, 20 Trans. Grotius Soc. 123 (1935); Westlake, International Law 293 (2d ed. 1910). Westlake emphasizes the importance to draftsmen of a "large and liberal spirit of interpretation" and urges that "a style of drafting accommodated to the expectation of a very literal interpretation would necessitate the suggestion and discussion of so many possible contingencies, as would be likely to cause needless friction between the representatives of countries not always very amicable."

39. See note 36 supra.

40. HARVARD RESEARCH, op. cit. supra note 30, at 946.

41. Id. at 937 .

42. One of the authorities that the Harvard Research quotes is Vattel, who wrote: "The motive of the lawe, or of the treaty, that is to say, the purpose which the parties had 
the overwhelming weight of authority, official and unofficial.43 Professor Lauterpacht has even summarized:

in mind, is one of the surest means of fixing its true sense, and careful attention should be paid to it whenever there is question either of explaining an obscure, equivocal, or undetermined passage in a law or treaty, or of applying it to a particular case. When once the purpose which has led the speaker to act is clearly known his words must be interpreted and applied in the light of that purpose only. Otherwise he would be made to speak and act contrary to his intention and to the object he had in view." Droit des Gens, Bk. II, ch. 17, sec. 287, Classics of Internationat Law 207 (Fenwick trans.).

43. See citations notes 37 and 38 supra. A wide sampling of the literature on interpretation ss offered by SoHN, CASEs aNd MATERTaLs oN WorLd LAw 15 (1950).

Highest official authority for the paramount importance of this principle is found in the recent Advisory Opinion of the International Court of Justice on Reparation for Injuries Suffered in the Service of the United Nations (Advisory Opinion of April 11, 1949. I.C.J. Reports 1949 , p. 174). In this case, the Court held that, despite the absence of any express provision in the Charter conferring such capacity, the United Nations has the capacity to bring international claims against responsible governments for injuries suffered by its agents in the course of duty. The court stated: "Under international law, the organization must be deemed to have those powers which, though not expressiy provided for in the Charter, are conferred upon it by necessary implication as being essential to the performance of its duties." In justifying its ascription of "legal personality" to the organization, the court reasoned: "In the opinion of the Court, the organization was intended to exercise and enjoy, and is in fact exercising and enjoying, functions and rights which can only be explained on the basis of the possession of a large measure of international personality and the capacity to operate upon an international plane. It is at present the supreme type of international organization, and it could not carry out the intentions of its founders if it was devoid of international personality. It must be acknowledged that its members, by entrusting certain functions to it, with the attendant duties and responsibilities, have clothed it with the competence required to enable those functions to be effectively discharged."

Another recent decision by the International Court of Justice applying the same principle is its Advisory Opinion on the International Status of South-West Africa (Advisory Opinion of July 11, 1950) which held that the mandates created under the League of Nations with respect to South-West Africa continued in force despite the dissolution of the League. The court reasoned: "These obligations represent the very essence of the sacred trust of civilization. Their raison d'etre and original object remain."

One may, of course, find occasional examples of the Court taking a narrower view of its function as interpreter. In the case of Interpreting Peace Treaties with Bulgaria, Hungary and Romania (Advisory Opinion of July 18, 1950), which treaties provided for a three-man commission to settle disputes arising out of their application, the Court refused to sanction the constitution of a commission in face of the refusal of the Balkan countries to appoint their representative, since this would be contrary to the "letter and spirit" of the treaties. (Italics supplied.) I.C.J. Rep. 229 (1950). This does not, therefore so much represent a rejection of interpretation by purpose as a finding that the interpretation asked for in the case at hand was contrary to the purpose of the treaties. Consequently, the decision cannot be used to bolster arguments for an allegedly literal interpretation of Article 27(3) unless it can also be shown that such "literal" interpretation is more in conformity with the purpose of the Charter than other interpretations.

The particularly cogent dissent of Judge Read in the Peace Treaties case, demanding application of the principle of effectiveness, appears more in accord with traditional attitudes of the Court than some of the language in the majority opinion. Offering a rich citation of precedent, Judge Read summarizes: 
". . The work of the Permanent Court has shown that alongside the fundamental principle of interpretation, namely, that effect is to be given to the intention of the parties, full use can be made of another hardly less important principle, namely, that the treaty must remain effective rather than ineffective. Res magis valeat quam pereat. It is a major principle, in the light of which the intention of the parties must always be interpreted, even to the extent of disregarding the letter of the instrument and of reading into it something which, on the face of it, it does not contain." 44

Fortunately, it is not necessary to do violence to the words of Article 27(3) of the United Nations Charter in order to give those words a meaning which will promote, rather than defeat, the purposes for which the United Nations was established.

\section{Charter Purposes and Provisions}

It may aid in making rational choice among the competing, alternative interpretations of Article 27(3) to recall that, after Preamble recitals of the determination of the peoples of the United Nations "to save succeeding generations from the scourge of war" and "to ensure, by the acceptance of principles and institution of methods, that armed force shall not be used save in the common interest," the first of the stated "Purposes of the United Nations" in Article 1 of the Charter is "to maintain international peace and security, and to that end: to take effective collective measures for the prevention and removal of threats to the peace, and for the suppression of acts of aggression or other breaches of the peace. . . ." The several other major purposes of the United Nations are all related to this primary purpose of maintaining peace and security, and the Charter, as is well known, establishes its elaborate institutional machinery with explicit emphasis upon this primary purpose. The United Nations was, thus, founded upon the assumption that the best way to promote lasting peace is through a system of collective security, which can both suppress

"The Permanent Court, when called upon to interpret arbitration clauses of widely varying types, with provisions for the settlement of international disputes, did not hesitate to adopt and apply broad liberal interpretations, designed to make them workable and to give practical effect to the evident intention of the parties as shown by the provisions of the treaties in which the clauses were included. To ascertain their intention, the Permanent Court examined each treaty as a whole, in order to learn its general purpose and object."

44. Lauterpacht, The Deveioparent of International Law 69-70 (1930).

This may be called the principle of the continuing validity of basic intent, as contrasted with an ephemeralism which disregards major goals and expectations when unanticipated events reveal ambiguities in intent about details.

For recent eloquent statement of this principle see the dissenting opinion of Judge Alvarez in Advisory Opinion on Competence of the General Assembly for the Admission of a State to the United Nations, March 3, 1950. 
aggression and give warning to potential aggressors that aggression does not succeed. ${ }^{45}$ The attack upon South Korea was an act of aggression pure and simple. To have allowed it to go unopposed would have spelled the end of the United Nations as an effective instrument for collective security. The choice which confronted the members of the Security Council who were present at the meetings in June was, therefore, whether they would permit the absence of one member to reduce the whole United Nations to impotence, and perhaps bring the organization to complete destruction, or whether they would act promptly and decisively to secure the primary purpose for which the organization was established, and perhaps to save the world from a new and more dreadful conflagration. The Security Council, interpreting its own powers as it was competent to do under the Charter, chose action rather than inaction. The burden upon a disinterested observer who today in retrospect would stigmatize this action as "illegal" because of some alleged literal and unambiguous meaning of Article 27(3) is, we submit, most substantial. ${ }^{46}$

Apart from its own and other prior authoritative interpretations of Article 27(3), which will be reviewed below, the Security Council had in direct affirmative support of its Korean action certain other provisions of the Charter, indispensable to any comprehensive interpretation, which indicate that the function of the United Nations as an instrument for collective security is designed as a permanent one, too important to be frustrated by the whim or caprice of any individual member. By Article 24 the members of the United Nations, "in order to ensure prompt and effective action by the United Nations," confer on the Security Council "primary responsibility for the maintenance of international peace and security, and agree that in carrying out its

45. The importance of the United Nations as an instrument of collective security against aggression has been emphasized increasingly in the world-wide debate of recent months: "There is only one real way the world can maintain peace. ... That is by strengthening its system of collective security. Our best hope of peace lies in our ability to make absolutely plain to potential aggressors that aggression does not succeed. The security of those nations who want peace and the security of the United Nations itself, demands the strength to prevent further acts of aggression." Secretary of State Acheson before the General Assembly, N.Y. Times, Sept. 21, 1950, cols. 1-8. See also the speech of John Foster Dulles, N.Y. Times, Oct. 10, 1950, p. 10, col. 1-8. Similar statements abound in the speeches of the foremost policy-makers of all the non-Soviet states.

46. By "disinterested" we mean an observer who is not party to the immediate dispute; we do not mean an observer without preferences or values he is seeking to implement by his interpretation. It may be helpful to dispel once and for all the notion that the Charter, or any other international agreement, is susceptible of "objective" interpretation "in spite of its political and ideological overtones." See Gross, supra note 9, at 257. Interpreters whose interpretations make any difference are dealing not with meaningless logical symbols in a dematerialized world but with words employed by human beings in specific contexts for certain very real purposes, and no interpreter, with moderate claim to rationality, can ignore either the effects of alternative decisions upon these people and their purposes or 
duties under this responsibility the Security Council acts on their behalf." For discharge of this responsibility Article 28(1) provides:

"The Security Council shall be so organized as to be able to function continuously. Each member of the Security Council shall for this purpose be represented at all times at the seat of the Organization." (Italics supplied.)

Introducing an "important departure from League practice," these provisions indicate the expectations of the members that the Security Council was to function continuously. ${ }^{47}$ Interpretation must give meaning and effect to these provisions as well as to Article 27(3) and it is in the context of these provisions that Article 27(3) must be read, however literal an interpreter seeks to be. ${ }^{48}$ "These provisions," a Canadian observer writes, "could hardly operate or have real meaning if any permanent member of the Council were able to disrupt the continuous functioning of the Council by simply instructing its delegate not to appear at its sessions." 49 The interpretation adopted in fact by the Security Council gives, in contrast, to all articles of the Charter a most rational meaning-that best designed to promote the primary purpose of the organization.

the compatibility of such effects with the major purposes the community had in establishing him as an interpreter. For discussion of the general point and precedent, see HudsoN, $o p$. cit. supra note 22 , at 656 , who summarizes that the relevance of "political and social" factors "has been appreciated by the Court [Permanent Court of International Justice] in a long course of action."

With respect to the Charter, an early commentator wisely remarked: ". . . the Charter is a political document, which means that political considerations should be given full scope in the process of interpretation. . . . Law cannot be applied in a social vacuum, but must always have certain relations to the circumstances in which it is going to be applied." Pollux, The Interpretation of the Charter, 23 BRIT. Y.B. INT'. L. 54, 68 (1946).

In its Advisory Opinion on Reparation for Injuries Suffered in the Service of the United Nations, supra note 43, the International Court of Justice builds explicitly upon this wisdom to justify its decision:

"It must be added that the organization is a political body, charged with political tasks of an important character, and covering a wide field, namely the maintenance of international peace and security, the development of friendly relations among nations, and the achievement of international co-operation in the solution of problems of an economic, social, cultural or humanitarian character . . . and in dealing with its members it employs political means."

47. See Goodrich \& Hambro, Charter of the United Nations-Commentary ANd Documents 227 (2d ed. 1949).

Reference may be made also to Article 2(2) which provides: "All members, in order to insure to all of them the rights and benefits resulting from membership, shall fulfil in good faith the obligations assumed by them in accordance with the present Charter."

48. It is no answer to urge that violations of Articles 24 and $28(1)$ by the Soviet Union do not give the other powers the right to violate Article 27(3). See Gross, supra note 9, at 249-50. The point is that when Article 27(3) is read in the context of Articles 24 and $28(1)$, the Korean resolutions do not violate Article 27(3).

49. Hopkins, Case and Comment, 28 CAN. B. REv. 908, 910 (1950). 
Another factor substantiating the expectations of the members of the United Nations that their organization should be able to function continuously as an instrument of collective security is the omission from the Charter of any provision for withdrawal by member states. Seeking to avoid a basic weakness of the League Covenant, the Dumbarton Oaks proposals deliberately omitted provisions for withdrawal. At San Francisco a separate declaration of interpretation was eventually adopted by the Conference which recognized a right of withdrawal under certain circumstances. ${ }^{50}$ However, the long discussion which preceded the adoption of this declaration reveals strong demands among the member states for the permanency of their organization. One sub-committee report was "strongly of the opinion that withdrawal should be impossible." "51 Among the reasons advanced for not permitting withdrawal was "that the possibility of withdrawal would give recalcitrant members the opportunity of securing concessions from the organization by threatening to leave it." "52 Furthermore, neither in the discussions of withdrawal nor in the discussions of other Charter provisions does the suggestion appear that the departure of a member, even a permanent member, would interrupt the operation of the United Nations. ${ }^{52^{2}}$ In such a climate of opinion it could scarcely have been a common expectation that one member state could by its wilful absence bring the whole organization to paralysis.

\section{The Ambiguities of Article 27(3)}

In the light of all these considerations, it is hardly surprising to find that the words of Article 27(3) have not in fact been interpreted as

50. For discussions of this history see Goodrich \& HaMrro, op. cit. supra note 47, at 142; KELSEN, op. cit. supra note 23, at 122; SoHN, op. cit. supra note 43, at 250. at 122 .

51. U.N. Conf. Doc. 1074, I/2/76 (1945), discussed in KELSEN, op. cit. supra note 23,

52. KELSEN, op. cit. supra note 23, at 122.

$52 \mathrm{a}$. On the contrary, the suggestion that the United Nations was to continue as an effective instrument for the maintenance of peace despite the departure of any member can be found in the Report of Committee I/2, subsequently approved by Commission I and the Conference in Plenary Session. See GoodrIcH \& HaxrrRo, op. cit. supra note 47, at 143: "The Committee deems that the highest duty of the nations which will become Members is to continue their cooperation within the Organization for the preservation of international peace and security. If, however, a Member because of exceptional circumstances feels constrained to withdraw, and leaves the burden of maintaining international peace and security on the other Members, it is not the purpose of the Organization to compel that Member to continue its cooperation in the Organization." (Italics added.) Goodrich and Hambro conclude that if withdrawal "is accompanied or followed by a threat to or violation of the peace, the United Nations is obligated and empowered to take the same measures to maintain or restore the peace which would be taken if the state in question had remained a Member." Id. at 145 . This conclusion is reinforced by reference to Article 6 of the Charter, which provides for the expulsion of any Member which persistently violates the principles of the Charter. Article 6 would not make sense if ex- 
having the single "unambiguous" meaning demanded by the interpreters who describe themselves as "objective." Even before the issue was raised with reference to Korea, there was among commentators - as there was in practice-considerable support for an entirely different interpretation. As summarized by Professor Kelsen, "the wording of Article 27, paragraph 3, allows two different interpretations." ${ }^{53}$ Under the first interpretation, the concurring votes of all five permanent members are required and the abstention or absence of one such member precludes a valid decision. Under the second interpretation, the "concurring votes of the permanent members" may be taken to mean the concurring votes of the permanent members who participate in the voting. ${ }^{54}$ In this view, the one adopted in practice by the Security Council, a substantive resolution requires only the votes of those permanent members who attend a meeting and take a positive or a negative stand. Neither the abstention nor absence of a permanent member can prevent the passage of a resolution. It is this second interpretation that Messrs. Goodrich and Hambro adopt in their manual on the Charter of the United Nations. They conclude, after a review of the origin and application of Article 27(3), that absence has come to be "regarded as having the same legal effect, so far as voting is concerned, as an abstention" and, hence, that "it would appear that absence of a permanent member does not prevent the Security Council from taking a decision on a substantive question." 55

The suggestion that the phrase "the concurring votes of the permanent members" can yield only to the interpretation that all five must vote is belied not only by the judgment of other authoritative contemporary interpreters but also by the interpretation of comparable language in the League of Nations Covenant. The fallacy of an impossible "literalism" had as little effect upon the interpretation of the Covenant as it has had upon that of the Charter. Article 5, paragraph 1 of the League Covenant read:

"except where otherwise provided for in this covenant or by the terms of the present Treaty (of Versailles) decisions at any meeting of the Assembly or of the Council shall require the agreement of all the Members of the League represented at the meeting."

If the same "strict" interpretation demanded for Article 27(3) of the Charter, by those who attack the Korean resolution, had been applied to the phrase "agreement of all the Members of the League represented at the meeting" the conclusion would have been drawn that, to carry a resolution, every member present at a meeting was required to cast

pulsion of a member resulted automatically in the destruction of the entire organization.

53. Id. at 240 .

54. Id. at 240 and 241.

55. Goodrich \& HaMrbro, op. cit. stupra note 47, at 223 (2d ed. 1949). 
an affirmative vote-in other words, that an abstention from voting was a veto on League action. Such an interpretation, however, was specifically rejected. Abstaining votes were consistently disregarded and this practice was eventually incorporated in Article 9, paragraph 3 of the Council's Rules on Procedure. ${ }^{56}$

Still another example of interpretation from League experience is relevant. Article 16, paragraph 4, in language similar to that of Article 27, read:

"any member of the League which has violated any covenant of the League may be declared to be no longer a Member of the League by a vote of the Council concurred in by all the other members of the League represented thereon."

A "literal" interpretation of "all the other members of the League represented thereon" would have held the phrase capable of only one meaning, namely, that every member represented on the League Council other than the offending member was required to cast an affirmative vote in order to expel a League member. Yet when the Soviet Union was expelled from the League of Nations in 1939, four members abstained and two members were absent. No one, not even the Soviet Union itself, challenged the legality of this vote. It remained for one of the present proponents of "illegality" in Korea to raise the same charge with reference to the expulsion of Russia from the League some six years after that expulsion had taken place. ${ }^{57}$

56. See, e.g., Stone, 14 BRIT. Y.B. INT'L L. 31 (1933). The interpretation of this article of the Covenant, as well as of Article 16, paragraph 4, infra, especially emphasizes the measure of assumption involved in calling the language of Article 27(3) of the U.N. Charter "unambiguous." In both Articles of the League Covenant, the word "all" appeared, and in both cases literal interpretation of the type urged by the attackers of the Korean resolutions, was rejected. By analogy, the presence of the word "all" in several foreign language texts of Article 27 (3) makes no difference. The Article can still be read, as the Security Council does read it, "the concurring votes of all the permanent members present and voting."

The Harvard Research Draft Code provides that where the text of a treaty is embodied in equally authoritative versions in different languages "the treaty is to be interpreted with a view to giving to corresponding provisions in the different versions a common meaning which will effect the general purpose which the treaty was intended to serve." A conflict in words thus gives rise to no new principle.

57. The phrases of Professor Gross' article supra have a familiar ring: "No useful purpose would be served by denying that, assuming the above interpretation to be correct, the Council could under certain conditions be prevented from taking necessary decisions under Article 16, paragraph 4. This may be regrettable, but it would seem that the precise words of paragraph 4, Article 16, leave no room for the introduction of 'legal correctives.' If a state which is entitled to be represented on the Council is, by design, not so represented, and this prevents the Council from declaring a Covenant-breaking state no longer a Member of the League, the consequence is the same as if that state had exercised the veto power to which it is entitled. The same is true of states which are represented on the Council 


\section{Legislative History of Article 27(3) Confused}

To be sure, the proponents of the theory that absence equals a veto do not rest their case entirely on the language of Article 27(3). They profess to find in the historical events preceding the drafting of Article 27(3) evidence to support the proposition that the authors of the document intended the Council to be powerless in the absence of a permanent member. If intent is not being used in a loose sense to justify conclusions reached on other grounds, then this assertion can only mean that the framers of the Charter actually anticipated that a permanent member would wilfully absent itself from the Council and that they were of the common opinion that the major purposes of the organizations would be best served if paralysis should result. Nothing in the legislative history of Article 27(3) compels such a conclusion. As a matter of fact, there was considerable confusion at the San Francisco Conference concerning the precise meaning of the voting provisions. ${ }^{58}$ The various delegates were not agreed on whether Article 27(3) required the votes of all five permanent members, or whether it required only the votes of those members who were present and voting. Evidence of this confusion may be found in the report of Committee I of Commission III:

"Speaking of the effect of an abstention from voting by one of the permanent members, the Delegate of El Salvador repeated a question previously asked of the sponsoring governments as to whether abstention would be considered as an exercise of the veto. He pointed out that until the question was answered he would be unable to decide whether or not to propose a specific amendment on the matter, and he felt that other delegates were in the same position." 59

The Australian delegate inclined toward the theory that the affirmative votes of all five permanent members were required but he agreed that the point was important and suggested that it be "recorded and forwarded to the sponsoring governments for their consideration." 60 The question raised by El Salvador was never answered, and there is

but which refrain from taking part in the vote." (Italics added.) Gross, Was the Sovict Union Expelled from the League?, 39 AMr. J. INT'L L. 39 (1945).

58. "It was soon clear that the Sponsoring Governments themselves were not in agreement as to the interpretation to be given." GoodRICH \& HAxsBRo, op. cit. supra note 47, at 215.

59. Meeting of Committee III/1, Doc. No. 967, 11 U.N. Conf. Doc. 513 (1945).

60. Id. at 516. The question was submitted to the Sponsoring Governments in the following form: "If a motion is moved in the Security Council on a matter, other than a matter of procedure, under the general words in paragraph 3, would the abstention from voting of any one of the permanent members of the Security Council have the same effect as a negative vote by that member in preventing the Security Council from reaching a decision in the matter?" Doc. III/1/B/2(a), id., p. 707. 
no reference to it in the explanation of the voting formula contained in the Statement of the Four Sponsoring Powers. Thus, to use the words of one authority, the provisions of Article 27(3) in this respect were "left obscure and subject to interpretation." 61

It may seem strange that this obscurity or ambiguity in the words of Article 27(3) was never remedied at San Francisco. But the political factors which produced the voting provisions could hardly permit any other result. The language of Article 27(3) was agreed to at the Yalta Conference after great difficulty and compromise. ${ }^{62}$ Its wording was preserved intact at San Francisco not so much because the great powers were unanimous in their conception of its "meaning" but rather because any changes in the text might require the reopening of painstaking negotiations and threaten the whole future of the organization. This was demonstrated when the Canadian delegate submitted an amendment to Article 27(3) which would have required "an affirmative vote of at least two thirds of the members present and voting." 63 The question of abstention and absence might have been settled by this amendment once and for all. But the Soviet delegate felt the introduction of the amendment at this time "would lead to difficulties." "64 Consequently, the Canadian delegate withdrew the amendment, urging that "the sponsoring governments take the matter under consideration." ${ }^{65}$ Even those who contend that absence is the equivalent of a veto have to admit that the confusion and lack of agreement at the San Francisco Conference were never finally resolved. ${ }^{66}$

Support for the proposition that the framers intended absence to act as a veto is, nevertheless, sought in the words or actions of the great powers themselves. One report has been found-never corroborated-that the great powers had an understanding with one another to this effect. ${ }^{67}$ The conditions of their understanding and the exact degree to which they may have sought to anticipate future contin-

61. Liang, Abstention and Absence of a Permanent Member in Relation to the Voting Procedure in the Security Conncil, 44 AM. J. INT'L L. 694, 695 (1950).

62. A useful summary of the Yalta discussions on the U.N. voting formula can be found in 2 SHERwood, Roosevert AND Fopkins 496-7 (Bantam ed. 1948).

63. Meeting of Committee III, II, 1, U.N. Conf. Doc. 515 (1945).

64. Ibid.

65. Ibid.

66. The recital by Professor Gross is enough to establish this point.

Professor Gross writes: " . . it was an error of the first magnitude to overlook the necessity of providing for the contingency that unanimity might not be forthcoming in cases in which, politically, inaction of the council would not be acceptable." Gross, supra note 9 , at 251 .

One can only wonder how compatible the admission that the framers did not anticipate this contingency is with the argument that Article $27(3)$ embodies an unambiguous intent of the framers with respect to such contingency.

67. See Koo, Voting Procedures in Internatronal Polmtical Organizations 156 (1949). 
gencies, such as the case of Korea, remains shrouded in obscurity. Even if it existed and was reasonably clear, such an understanding between the great powers, never having been expressed, can hardly be conclusive evidence of the intent of the other parties to the Charter. It is frequently forgotten that the founders of the United Nations numbered not five but fifty, and that the largest powers cannot be presumed to speak for all.

The same point may be made with even greater emphasis with regard to the oft-quoted Statement of the Four Sponsoring Powers. This statement has little legal significance apart from its value as evidence of the intent of the five permanent members. Even as evidence of such intent, the statement is far from conclusive. The so-called "principle of unanimity" referred to in the statement does not have to be interpreted to mean paralysis of the Security Council in the face of the wilful absence of a permanent member. On the contrary, there is language in the Statement to indicate that the great powers intended no such result. "It is not to be assumed," they said, "that the permanent members, any more than the non-permanent members, would use their veto willfully to obstruct the operation of the Council." "ss Evidence of intent to the same effect can be found in the General Assembly resolutions passed during the first session of the Assembly calling upon the permanent members to find means of "reducing the difficulties in the application of Article 27 and to ensure the prompt and effective exercise by the Security Council of its functions." 69

One final reference to the Four Power Statement may still further refute the contention that paralysis of the Council was anticipated as a result of the absence of a permanent member. The veto was imposed by the big five upon the other 45 powers at San Francisco only after careful explanation that the provision was not a step backward, but a step forward from the League of Nations system which required the unanimity of all the powers. Thus, the Statement declared the Security Council would be able to operate with greater dispatch than the Council of the League:
"The Yalta voting formula substitutes for the rule of complete unanimity of the League Council a system of qualified majority voting in the Security Council. . . . As regards the permanent

68. 11 U.N. Conf. Doc. 714 (1945). This assumption that the power of veto would not be abused is reflected in the Statement of Secretary of State Stettinius to the Senate Foreign Relations Committee: "There is still another, and more compelling reason why the power of veto is not likely to be abused, or even to be exercised at all except in unusual circumstances. That is the compelling desire and need of the five great nations to work together for peace. ... It is in the vital national interest of each one of them to see that these obligations and responsibilities are fulfilled." Senate Committee on For. Rel. 216 (1945).

69. General Assembly Resolution 40 (I), December 13, 1946. 
members, there is no question under the Yalta formula of investing them with a new right, namely, the right to veto, a right which the permanent members of the League Council always had. The formula proposed for the taking of action in the Security Council by a majority of seven would make the operation of the Council less subject to obstruction than was the case under the League of Nations rule of complete unanimity." 70

If, at the time of writing this, the great powers intended the wilful absence by one of them to have the effect of causing paralysis in the Security Council, then this statement represents a fraud upon the other 45 parties to the United Nations Charter. For giving a great power the ability to veto action without being present is a "new right" never enjoyed under the League and does not represent a development which would make the Council "less subject to obstruction." It can hardly be said, therefore, in the light of all this history, that the framers of the Charter had the clear "intent" to make absence equivalent to a veto. A babel of different attitudes and unanswered questions offers no support to any particular literalism.

\section{Interpretation by Purpose Confirmed in Practice}

The most decisive answer to the proponents of an allegedly strict interpretation of Article 27, however, comes from the practice of the United Nations itself, in the way the member nations and the various agencies of the organization have in fact acted upon the language of the Article. The Security Council has never interpreted its voting provisions to require the affirmative votes of all five permanent members, whether or not they were voting or present. Even before the Soviet Union left the Security Council in January, 1950, some forty substantive decisions had been passed by the Council with the abstention of one or more of the permanent members. These decisions represent nearly four-fifths of the substantive decisions taken by the Security Council in the 458 meetings between January 17, 1946 and December 29,1949 . The practice of abstention, in fact, was originated by the Soviet Union. Furthermore, no substantive proposal was ever defeated because a permanent member abstained from voting and most of the decisions in which permanent members abstained were passed unchallenged in the Council. ${ }^{71}$ If the "strict" interpretation of Article 27(3) is correct, then the bulk of the work in the Security Council is invalid. Of course, it is precisely the contrary interpretation which authoritative surveys show to be "established and generally recognized." 72

70. 11 U.N. Conf. Doc. 713 (1945).

71. For documentation and elaboration of these statements see Liang, supra note 61, at 696 et seq.

72. Id. at 707 . 
This interpretation represents no new development but was articulated by the President of the Council as early as August 1, 1947:

"I think it is now jurisprudence in the Security Council-and the interpretation accepted for a long time- that the concurrent votes of the permanent members means the concurrent votes of the permanent members who participate in the voting. Those who abstain intentionally are not considered to have cast a veto. That is quite clear." 73

These remarks were directed specifically toward the practice of abstention, but they are equally applicable in logic and policy, as will be developed below, to absence.

The proposition that absence is analogous to abstention in not amounting to a veto has precedent to support it, although not precedent as considerable as in the case of abstention itself. The lack of extensive precedent, however, is due not to lack of agreement on this point among the majority of Council delegates but rather to the infrequency with which the problem has arisen. Absence of a member of the Security Council, before the departure of the Soviet Union in January, 1950, occurred only twice. In both cases the members by their words and actions made clear that in the majority view absence was clearly analogous to abstention in failing to affect the work of the Council.

The problem was first precipitated by the withdrawal of the Soviet Union during discussion of the Iranian case of March 26, 1946. Despite this withdrawal, the Security Council continued to sit and to pass resolutions. There is some question as to whether these resolutions were of a substantive or procedural character, and therefore whether the Soviet Union, even if present, would have been entitled to employ its veto at all. Nevertheless, the Security Council, by proceeding in the absence of the Soviet Union, at least deprived the Soviets of their "double veto"- - that is, the power to veto the decision that the resolution was procedural and not substantive in character, something that the Soviet delegate would almost certainly have done. The suggestion that the Soviet Union could exercise the veto right by being absent was rejected with the remark that such a ruling would constitute a "very extensive de facto amendment of the provisions of the Charter" and "a very serious extension of the power of veto." "74 Sir Alexander Codogan, the British delegate, further commented:

- "... as regards the effect of absence upon the action of the Council, I cannot see that there is really any difference between

73. Security Council, Off. Rec., 2d year, No. 68, pp. 1711-1712.

74. These were the words of Mr. Hasluck, the delegate of Australia. Security Council, Off. Rec., 1st year, 1st ser. No. 2, pp. 248-250. 
absence from this table or presence at a table and abstention from

a vote. It seems to me that the general effect is the same." 75

When the problem of absence arose again, it was with reference to the absence of the Ukrainian delegate during the 392nd meeting of the Security Council. Though this was a case of the absence of a nonpermanent member, it is significant nevertheless as a guide to the attitude of the members of the Security Council toward the comparative effect of abstention and absence. After a vote was taken on the preamble of a draft resolution concerning the Indonesian question, the representative of the United States, Mr. Jessup, asked whether the absent member was counted as having abstained. The President of the Council replied: "It seems to me that he must be counted as having abstained. I do not see how we could act otherwise." There was no objection to this statement of the President. ${ }^{76}$

No other case of absence of a member of the Security Council arose until the departure of the Soviet Union on January 13, 1950, following the defeat of its resolution to unseat the representative of Nationalist China. Mr. Ernest Gross stated the position of the United States as follows:

"The absence of the Soviet Union will not prevent us from conducting the business to which we are pledged. It is the view of my Government that the absence of a permanent member from a meeting of the Security Council in no way diminishes its power or its authority to act." 77

The Security Council continued to function in the absence of the Soviet Union, passing at least two resolutions clearly substantive in character before the resolutions on Korea whose legality has been called in question. The Soviet Union did not contest the legality of the activity of the Council on the grounds of the absence of a permanent member until after the passage of the Korean resolutions, when, on June 29, 1950, it alleged that these resolutions had "no legal force" because they lacked the "concurring votes of all five permanent members." 78

This brief review of the practice of the Security Council makes clear that before the Korean resolutions the interpretation given to $\mathrm{Ar}$ ticle 27(3) in practice required the votes, not of all five permanent members, but rather only of those members participating in the voting. In his Law of the United Nations, Professor Kelsen states categorically that "in the practice of the Security Council absence of a member,

75. Id. at 251.

76. Security Council, Off. Rec., 3rd year, No. 134, p. 30.

77. Id. 5 th year, No. 3, p. 14.

78. See note 8 supra. 
even of a permanent member, does not prevent this body from adopting. a resolution. Absence of a permanent member is considered to be equivalent to abstention from voting." 79 More recently a distinguished jurist from within the United Nations concluded a careful survey with the statement that "the practice of the Security Council in this respect has been generally accepted." 80

It is gross misapprehension to attempt to write off this history of how the Security Council and member states have interpreted the powers of the Council as "mere practice." The decisions of the Security Council outlined above are, when correctly appraised, much more than evidence for justifying an interpretation. These decisions, including. the resolutions on Korea, are themselves authentic interpretations of the Charter by a body authorized to make such interpretations. It may be recalled that when the question was put to Committee II(2) at San Francisco of "how and by what organ or organs of the Organization. should the Charter be interpreted," the Committee answered:

"In the course of the operations from day to day of the various organs of the Organization, it is inevitable that each organ will interpret such parts of the Charter as are applicable to its particular functions. This process is inherent in the functioning of any body which operates under an instrument defining its functions and powers. It will be manifested in the functioning of such a body as the General Assembly, the Security Council, or the International Court of Justice. Accordingly, it is not necessary to include in the Charter a provision either authorizing or approving the normal operation of this principle." 81

79. See KeLsEN, op. cit. supra note 23, at 244-45. It is noteworthy that Professor Kelsen makes this statement in his section devoted to "quorum" requirements of the Council. This would appear to refute the suggestion of Professor Gross, that, since the Charter includes no express quorum requirements, it requires the presence of all eleven members or at least of all five permanent members. See Gross, supra note 9, at 245 . The first suggestion, that the absence of quorum requirements means that all members must be present in all situations in order to pass a resolution, has little to support it. The second, that all five permanent members must be present, is based on the proposition that a quorum requires at least those members necessary to pass a resolution. But this only puts the issue back where it was at the beginning: what members are in fact required to pass a resolution and what is the rational interpretation of Article 27(3)? For this reason, the "quorum" discussion of Professor Gross adds nothing to his general thesis and only serves to emphasize the circularity of the entire argument.

80. Liang, supra note 61 , at 708. One of the proponents of "illegality" concedes in broad terms the practice of the Council in overlooking absence as well as abstention: "Dating from the withdrawal of the representative of the USSR from the Council in 1946 the voluntary absence of a member from the Council when a vote was taken has been regarded as equivalent to an abstention. Although this interpretation does not have the same wealth of precedent to support it, it seems entirely logical and has never been challenged." Note, 28 CAN. BAR. REv. 902 (1950).

81. Meeting of Committee IV/2, Doc. 933, 13 U.N. Conf. Doc. 709 (1945). 
Even considered, however, as mere evidence for disinterested interpretation by others, such a long and uniform line of decision by the Security Council itself is entitled to great weight. The importance of practice in the interpretation of great constitutional documents, international as well as national, ${ }^{82}$ has long been recognized and is today commonly accepted. ${ }^{83}$ The interpretations in practice by the parties who must live and work under an agreement both embody the lessons of the parties' experience in seeking to make the agreement effective and exhibit their own continuing conception of their powers and obligations under the agreement. Some four years ago a commentator on The Interpretation of the Charter made the prophecy that:

"The Charter, like every written constitution, will be a living instrument. It will be applied daily; and every application of the Charter, every use of an Article, implies interpretation; on each occasion a decision is involved which may change the existing law and start a new constitutional development. A constitutional customary law will grow up and the Charter itself will merely form the framework of the organization which will be filled in by the practice of the different organs." $\$ 4$

How completely this prophecy has been fulfilled in fact can be seen in any account of the United Nations' activities. ${ }^{85}$

82. Among the more famous expositions is that of Mr. Justice Holmes in Missouri v. Holland, 252 U.S. 416, 433 (1920) : “. . . when we are dealing with words that are also a constituent act, like the Constitution of the United States, we must realize that they have called into life a being the development of which could not have been forseen completely by the most gifted of its begetters. It was enough for them to realize or to hope that they had created an organism; it has taken a century and has cost their successors much sweat and blood to prove that they created a nation. The case before us must be considered in the light of our whole experience, and not merely in that of what was said a hundred years ago."

An historical survey of United States' Supreme Court action prompts one observer to comment: "Whatever the Court has said, it has repeatedly made concessions to governmental practise and governmental need. Whatever the court has said, it has repeatedly turned to established governmental practise in search of norms. Whatever the court has said, it has shaped the living Constitution to the needs of the day as it felt them." Llewellyn, supra note 25, at 40 . See also Swisher, The Growth of Constitutional Power IN THE UNITED States (1945); McDougal \& Lans, supra note 29, at 212, 290.

83. HARVARD RESEARCH, op. cit. supra note 30 , at 966.

Note the emphasis on practice by the International Court of Justice in its Advisory Opinion on Reparation for Injuries Suffered in the Service of the United Nations, note 43 supra.

84. Pollux, The Interpretation of the Charter, 23 BRrr. Y. B. INTL L. 54 (1946).

Compare the suggestion of President Wilson, M. Clemenceau, and Mr. Lloyd George that "the articles of the Covenant are not subject to a narrow or technical interpretation." HUdSON, op. cit. supra note 22, at 651 n. 45.

85. See Goodrich \& HAMrBRo, op. cit. supra note 47; KeLSEN, op. cit. supra note 23.

Schachter in his Review, supra note 27, concludes that "many of us are grateful that we have at least an instrument for world order and, more important, that this instrument is 
Unilateral Dictation A Misconception of Unanimity: ABSENCE Versus Abstention

One alternative for challengers of the validity of the Korean resolutions is to declare "illegal" every decision the Security Council has taken in the face of either the abstention or absence of a permanent member-in other words, the bulk of what the Security Council has done during the last five years. As fantastic as it may seem, this is the position of one commentator who insists, despite all legislative history and interpretation in practice, that "the language used in Article 27 of the Charter leaves no room for doubt as to the intention of the draftsmen"! ${ }^{86}$ A more moderate, if not more tenable, alternative is to argue that the words of Article 27(3) can be interpreted to permit decisions in the face of abstention but not in the face of absence. ${ }^{87}$ This position gives its proponent the tactical advantage of challenging the legality only of those resolutions passed during the absence of the Soviet Union in the spring and summer of 1950, and of the resolutions concerning Korea in particular. Whatever may be said for the ingenuity of this approach, not much can be said for its consistency. The proponent of an "objective," single-meaning, interpretation can scarcely eat his cake of "literalness" for abstention and still have it for absence. If the "concurring votes of the permanent members" means the affirmative votes of all five members-the allegedly literal interpretation contended for-then it can yield neither to absence or abstention. If, on the other hand, the language of Article 27(3) is broad enough to permit an exception in the case of abstention, it is broad enough to permit an exception in the case of absence.

In the last analysis, therefore, those who urge a distinction in the legal effects of absence and abstention do not really do so on the grounds of literal interpretation. They argue instead on grounds of policy, a policy they purport to find in an arbitrary and entirely unsupported application of the "principle of unanimity." According to this theory, abstention is "tacit consent" and, though the honoring of resolutions adopted despite abstention constitutes an "exception" to Article $27(3)$, such honoring does not violate the "principle of unanimity." Absence, in contrast, is construed as explicit and specific dissent and hence is put forward as having the same legal effects as formal veto. Abstention, in the words of Professor Gross, "is a manifestation of consent in disguise." "[It] is not, of course," he continues, "consent in disguise or otherwise to the resolution in question; rather it is consent to the action which is to result from [it]. Such a manifestation, dis-

being construed not in terms of its deficiencies but in order to make effective its principles and purposes."

86. See Note, 28 Can. Bar. Rev. 902,906 (1950).

87. See Gross, supra note 9 ; Schick, note 9 supra at 311. 
guised or implied, cannot be said to exist if the permanent member in question, in official statements in communications, has made the imputation of such consent impossible." 88

This alleged distinction is as dubious in its assumption of fact as it is suicidal in its choice of policy. In the first place, it may be wholly inaccurate to call abstention "a manifestation of consent in disguise." Abstention may not be that at all. Abstention may occur when a member opposes a given resolution but dares not risk the odium of world opinion by unilateral obstruction of the resolution. It is but idle hair-splitting to distinguish between "the resolution in question" and "the action which is to result from it." Operational meaning can be given to the words in "the resolution in question" only by reference to "the action which is to result from it." Consent or opposition to the one can only be consent or opposition to the other. Abstaining members may in fact be in as much opposition to either the words of a resolution or the consequences that follow from the resolution as absent members. A particularly appropriate remark to this effect was made recently by a Soviet delegate:

"The United Kingdom representative . . . at today's meeting has stated our silence means assent with what the United Kingdom representative meant. ... I have to state that such an interpretation on the part of the United Kingdom representative is, to say the least, naive; a strange, droll interpretation. From my statement it is clear that we diverge from the United Kingdom position. ...

"Once again I wish to emphasize that my silence with regard to these questions does not mean assent. . . ." 89

Conversely, it may be equal error to assume that absence invariably means disagreement. A member may be absent for many reasons, which may not include opposition to specific resolutions. It may be that a member is by a general walk-out seeking to force completely unrelated concessions from other members. Can it be assumed, for example, that because the Soviet delegate left the Council in protest over failure to seat Nationalist China, that the Soviet Union was in opposition to every specific resolution introduced in the Council for the next six months? To make a distinction in the legal effects of absence and abstention depend upon some unexpressed state of assent or dissent in the nonvoting party would be as hazardous in application as it is unauthorized by the Charter. It may, of course, be argued, that there could be no doubt as to the Soviet position concerning the Korean resolutions. Such opposition was, in fact, made known by official

88. Gross, supra note 9, at 253. See also Schick, supra note 9, at 322.

89. P. M. Chernyshev before the Economic and Financial Committee of the United Nations General Assembly reported in the N.Y. Times, Nov. 4, 1950, p. 4, col. 2. 
statements and communications shortly after the resolutions were passed. Neither these communications and statements, however, nor any prevailing view as to the Soviet attitude toward the resolutions, can have any legal bearing. The Charter says nothing about informal communications or prevailing views. The fact is that the Soviet Union did not make its opposition to the resolutions known in the established manner, that is, by attending the meeting and exercising its power of speaking and voting.

It is the policy choice upon which it is based, however, that utterly and finally condemns this attempted distinction between absence and abstention. The practice that abstention is not a veto permits the United Nations to operate most effectively for the purposes of collective security for which it was designed. In contrast, a decision that absence is a veto, the choice that is urged by those who would reject the Security Council practice outlined above, would permit a single permanent member of the Security Council by its wilful refusal to participate in the deliberations of the Council, not simply to protect its own interests in inaction, but rather to impose upon the other members its views as to how they should or should not use their collective strength and thus, perhaps, to dictate to the whole organization a policy of futility and destruction. ${ }^{90}$ The express veto has itself proved enough of a hindrance to the effective operation of the United Nations. Anyone sincerely devoted to the major purposes of the United Nations must require the most compelling reasons, nowhere yet articulated, to justify a vast and unnecessary extension of the veto power by interpretation. The simple assertion that in the absence of the unanimity of the great - powers the Security Council cannot function "as an effective organ for the maintenance of international peace and security" 91 may or may not be true in fact. That issue, as we write, is still in fateful balance. To mistake so momentous an issue in fact and in rational choice for an issue in law, of legal necessity, can only enhance the danger of irrational and tragic resolution. Certainly no legal necessity, nothing in the words of the Charter, requires that the United Nations submit

90. At the other extreme it has been urged with some persuasiveness that a member state which wilfully absents itself in violation of Articles 24 and 28(1) can have no legal standing to protest action taken in its absence. This position was eloquently stated in the Council by the Representative of France:

"The delegation of the Soviet Union, by abandoning the Council, has abandoned the Charter. When it returns to the one and to the other, it will find again its right of speech, of criticism, of vote and of veto. So long as it has not done so, the USSR government has no legal or moral basis for contesting the action of the United Nations."

Some support for this position can be found in traditional doctrines of pacta stut servanda, HARVARD REsearcH, op. cit. supra note 30, at 977.

91. Gross, supra note 9, at 251. 
to the will of a single member or else destroy itself and the purposes for which it stands.

Any rational basis for comparison of abstention and absence must, therefore, be found in the purposes and effects which a member can pursue or achieve. A permanent member present at the Council Table who opposes a resolution has a choice: it can either veto the resolution and risk the censure of world opinion, or it can avoid responsibility for obstruction by abstaining and permitting the resolution to pass. It cannot impose its will on the other members and avoid the responsibility for doing so at the same time. So far no plausible reason has been advanced why this same standard should not be applied to an absent member. To require the veto to be exercised in a formal, open manner, for all the world to see and hear, imposes certain obvious limitations upon blackmail and unilateral dictation. To demand this open responsibility, discharged in council session, is not to fashion a principle about which a permanent member can reasonably complain. The express veto is more than adequate to protect any real interest. In the words of Ambassador Jessup:

"Clearly it can make no difference in terms of the application of the Charter on this point whether the representative of a permanent member sits at the table and abstains or whether he fails to come at all. The essential difference relates to the question of a member's willingness to discharge its obligations under the Charter. The Soviet Union had the legal power to attend the meeting of the Security Council and, by taking the responsibility before the world, to cast a veto to block Security Council action. The USSR did not have the power to block action by staying away from the meeting in violation of its obligations under Article 28." \$2

It is, as observed above, a complete misinterpretation of the "unanimity principle" to suggest that the Security Council must allow itself to be paralyzed by the wilful absence of a permanent member. It is not unanimity but impossible anarchy or tyranny to demand that "if unanimity fails, the will of one, however arbitrary, prevails over the will of many, however reasonable." 93 The "unanimity principle" was

92. Jessup, The United Nations and Korea, 23 Depr. of State Buld. 84, 86 (1950).

It may be emphasized that a member who is present, at least submits to the process of deliberation and negotiation. It exposes itself to the pressures of new information and of argument and counter-argument. The wilfully absent member, in contrast, rejects the process of negotiation for that of arbitrary coercion.

Comparison may also be made with the expectations, indicated in note 52a supra, about complete withdrawal from the United Nations. If the "principle of unanimity" does not require paralysis upon the complete withdrawal of a permanent member, it is difficult to see why a temporary, and perhaps illegal, departure should be accorded such effect.

93. Benjamin V. Cohen, speaking before the ad hoc Political Committee of the General Assembly on November 22, 1948, reprinted in Department of State, Voting and Membersinip in the United Nations, DePt. of State PUB. No. 3419 (February, 1949), p. 17, 19. 
never interpreted in such a way in the case of the League. ${ }^{94}$ There is no reason to interpret it in this way in the case of the United Nations.

Properly understood, the principle of unanimity represents nothing more than a recognition of the predominant importance for the future of international peace and security of continuing agreement among the great powers. It assumes "an honest and good faith" effort on the part of each of these powers to avoid using its strength to frustrate the purposes of the organization. ${ }^{95}$ Nothing in this principle suggests so restricted an interpretation of the voting provisions of the Charter as to make it impossible for the United Nations to take measures concerning the future of international peace without the complete agreement of the five major powers. The words of the Four Power Statement at San Francisco said only that the permanent members "could not be expected to assume the obligation to act in so serious a matter as the maintenance of international peace and security in consequence of a decision in which they had not concurred." ${ }^{96}$ This statement only recognizes what everybody knows, namely, that the United Nations is not yet strong enough to coerce a major power into employing its own military forces or taking any positive action in a course of conduct with which it does not agree. However, nothing in the Korean resolutions required the Soviet Union to act. Both the Resolutions of June 25 and June 27 were in the nature of recommendations under Article 39 rather than mandatory actions of the United Nations under Articles 41,42 , and 43 . They did not require the Soviet Union to commit Soviet military forces. Consequently, these resolutions did not violate the principle of unanimity, unless that principle is thought to mean that one major power can prevent other powers from using their forces in a course of action to which they have agreed. To give such a meaning to unanimity is required by nothing in history or reason. ${ }^{97}$ How much less does such a meaning appear in the literal words of Article 27(3)!

A similar position was taken recently by the delegate of Cuba: "The principle of unanimity of the permanent members of the Security Council is understandable in so far as it aims at the maintenance of international peace and security. It indicates that the great powers must reach agreement so that they may act in concert to maintain peace and security in the face of threats to or breaches of the peace. But that does not mean that the negative desire of one of these Powers should be enough to thwart the taking of effective measures to prevent and remove those very threats or breaches for ... the use and abuse of the veto are bound to lead to the negation of the function [of] the Charter . . ." Gutierrez before the General Assembly on Nov. 2, 1950. General Assembly, Off. Rec., 5th Sess., Provisional Verbatim Records of the 301st meeting, Doc. A/PV. 301, pp. 323-4.

94. See pages 273-74 supra.

95. Cohen, supra note 93.

96. 11 U.N. Conf. Doc. 714.

97. Compare the summary in Koo, Voting Procedures in International Political Organizations 10 (1947) : "Similarly the rule of unanimous consent in international conferences cannot mean anything more than this, that those who do not consent are not bound. It cannot properly be given the meaning, so often attributed to it, that no valid decision can 
"Uniting for Peace": The General Assembly Acts for Survival

The General Assembly has also, fortunately, gone on record as rejecting any such theory of unanimity and in favor of liberal principles of interpretation by major purposes. Interpretation of the Charter in terms of its primary design as an instrument of collective security prevailed in recent meetings of the Assembly to strengthen the machinery of the United Nations for resisting aggression. The General Assembly overwhelmingly adopted the proposals for "United Action for Peace," framed to enable enforcement action by members in cases where the Security Council is paralyzed by use of the veto. ${ }^{98}$ These proposals were also met by Soviet charges of "illegality" and it is worth examining these charges briefly to demonstrate the extremes to which advocacy of "strict" interpretation and single power domination can lead.

The heart of the resolutions of "United Action for Peace" passed November 3 by the General Assembly is the provision that an emergency meeting of the General Assembly can be held at 24 hours notice upon the vote of any seven members of the Security Council in the event that the Council is prevented by the veto from exercising its primary responsibility for international peace and security. Under this provision, the General Assembly would make "appropriate recommendation to members for collective measures, including in the case of a breach of the peace or act of aggression the use of armed force when necessary." Other provisions call for the establishment of a Peace Observation Commission working under the authority of the General Assembly to report on situations of international tension; a Collective Measures Committee to study methods for improving the machinery of collective security; and national contingents of member nations to be held ready to deal with cases of aggression. These resolutions represent the three elements basic to any system of collective securitya reliable means of information to apprehend aggression, a prompt and dependable central initiative to authorize enforcement measures, and a military power to carry out those measures. ${ }^{99}$ Since the veto prevents the Security Council from performing any of these functions, the General Assembly decided that it was necessary to organize new procedures under its own powers if such functions were to be carried out at all.

The same charge of "illegality" that followed the attempt to repel aggression in Korea was made against this new attempt to strengthen the capacity of the United Nations to resist aggression in the future.

be reached unless all the parties are in agreement. Obviously to interpret the unanimity rule in a conference as conferring a liberum veto upon every participating state would be to give the minority a right of interference with the actions of the majority."

98. General Assembly Resolution reprinted N. Y. Times, Nov. 4, p. 4, col. 3-5.

99. See the speech of John Foster Dulles before the General Assembly, Oct. 9, 1950 reprinted N. Y. Times, Oct. 10, 1950, p. 10, col. 1-8. 
Mr. Vishinsky, in debates before the General Assembly, stated the position of his government simply and clearly. In his view, the Security Council had the exclusive authority to take enforcement action under the Charter. If, in the absence of unanimity among the great powers, the Security Council was unable to take collective measures against aggression, the General Assembly was precluded from making attempts of its own to restore peace and security. For these conclusions Vishinsky cited that section of Article 12 which provides that the General Assembly shall not make recommendations "while the Security Council is exercising in respect to any dispute or situation the functions assigned to it in the present Charter." He cited also the provisions of Article 11, paragraph 2 to the effect that questions relating to the maintenance of international peace and security "on which action is necessary shall be referred to the Security Council by the General Assembly either before or after discussion." The letter of the Charter and the "principle of unanimity," it was contended, combined to render the "United Action for Peace" proposals entirely illegal. ${ }^{100}$

These arguments, like the arguments against the validity of the Korean resolutions, represent attempts to find in the Charter a "meaning" both more restrictive than that which the words in context require and more limited than that which has been permitted in practice or that which is required to effectuate the purposes of the organization. In the first place, the Security Council was given "primary," not "exclusive" responsibility for the maintenance of international peace. ${ }^{101}$ Nothing in the Charter requires the conclusion that the Security Council is the only organ that can be used to implement that purpose. The Charter does preclude the General Assembly from making recommendations while the Council is exercising its functions. But an interpretation designed to promote the major purpose of the United $\mathrm{Na}$ tions need not maintain, in oblivion to fact, that the Council is "exercising ... the functions assigned to it" when a veto by a permanent member prevents it from doing so. ${ }^{102}$

100. See the speeches of Vishinsky on October 10 and November 2, the first in the N. Y. Times, Oct. 11, 1950, p. 12, col. 1-7; the second in General Assembly, 5th Sess., Provisional Verbatim Records of the 301st meeting, Doc. A/PV.301, pp. 324-35.

101. U. N. CharTer, Art. 24.

102. Compare the remarks of Mr. Younger, of the United Kingdom, in General Assembly, 5th Sess., 300th Plenary Meeting, Nov. 2, 1950, at 307 :

"The Soviet Union and others, however, in an effort to prove that the resolution will weaken the Security Council, has attributed to the Council a power which it never had under the Charter, namely, the power to insist that, because the Council has itself been reduced to impotence in the face of aggression by disagreement among its permanent members, the entire World Organization shall wash its hands of the whole matter and let aggression take its course. The Council has never possessed any such right. Indeed, it is impossible to conceive that the authors of the Charter at San Francisco would have lent 
There is similarly little force in the reference to the necessity for the Assembly to refer to the Council questions relating to international peace "on which action is necessary." This has on a number of occasions been interpreted to refer only to mandatory acts of the Assembly, not to resolutions which rely only on the moral obligations of the members for their effectiveness. ${ }^{103}$ Such an interpretation is reinforced by reference to the requirement ${ }^{104}$ that these provisions "shall not limit the general scope" of the broad provisions of Article 10 enabling the General Assembly to "discuss any questions or any matters within the scope of the present Charter." It should be remembered that this provision was exacted by the small powers at San Francisco as the price of the veto. ${ }^{105}$

The almost unanimous adoptions by the General Assembly of the "United Action for Peace" resolutions represents an encouraging example of interpretation of the Charter in terms of its major purposes. This interpretation does indeed reflect a change in emphasis regarding the procedures by which the United Nations will deal with threats to international peace and security. It was originally hoped that there would be sufficient unanimity among the great powers to enable the organization to require the mandatory action of all the members to repel aggression. In the absence of that unanimity resort has been made to other provisions of the Charter enabling the United Nations to achieve security by recommending the voluntary action of its. members. There is nothing "illegal" about this change. It is simply a rational evolution, well within the words of the Charter, to meet new and unanticipated contingencies.

To call such a development a violation of the principle of unanimity is again to mistake the whole place of that principle in the United Nations system. ${ }^{106}$ This was effectively pointed out during the General Assembly debates by the delegate of Cuba:

"The Organization of the United Nations is in existence, and it is to be justified, uniquely and solely, in the achievement of those

themselves to a proposition so far out of tune with the hopes and wishes of the peoples of the world."

So also Mr. Pearson of Canada :

"The acceptance of Mr. Vishinsky's legal argument would merely mean that the United Nations cannot take any action at all to safeguard peace and security, if the Security Council is made powerless by any one of its members. We do not and cannot believe that the United Nations Charter sanctions any such futility."

103. In the Spanish, Greek, Palestine and Korean (1947) questions the General Assembly made recommendations of great importance for international peace and security. See, e.g., Goodrich \& HAMBRo, op. cit. supra note 47, at 169-71.

104. U.N. ChARTER, Art. 11, \$4.

105. This was emphasized by Dulles in his speech, supra note 99, at col. 3-4.

106. Mr. Pearson has made the point with vigor: "This draft resolution has been attacked, and very vigorously attacked, as aimed against, for one thing, the unanimity of 
aims for which it was set up. The Charter provides the procedures and means whereby it is possible to fulfill such aims. Among them is the principle of unanimity; it is a mere method, a means for the fulfillment of a function. When there is a dispute or a conflict between the means and the end, between the procedure and the function or aim which it tries to achieve, it is the first which loses its validity and it is the fundamental obligation of the Charter which prevails, namely, to seek by other means or other procedure, the achievement of the aims of the organization. . . ." 107

\section{Collective Defense Indispensable to World Order}

The principal issue in interpreting Article 27(3) and the other relevant provisions of the Charter is therefore sharp and clear: it is whether the vast majority of the members of the United Nations can so read their Charter, despite unanticipated obstructions, as to make the organization an effective instrument for collective security and its other purposes or whether a single member can impose its will to bring the organization and its purposes to ruin. ${ }^{10 s}$ The choice is, in a blunt literality for once relevant, a choice between life and death, between survival and destruction-not for the organization alone, but also for the peace and freedom it was designed to secure. It is indeed unfortunate that the hoped-for unanimity among the great powers has not been forthcoming, that only a few years after the end of the Second World War the peoples of the free world are faced with a new threat of unprecedented magnitude. It would be the worst kind of folly, however, to think that any "principle of unanimity" stands in the way of meeting that threat through the organized procedures lawfully provided for in the United Nations Charter. Member states that do not hang together and combine their strength, will certainly hang separately. Although there is not at present enough order in the world community, or strength in its organization, to compel participation in collective measures, there is no reason why the principles of right and justice agreed to by a majority of the United Nations should not be enforced on a voluntary basis. So modest a step toward an enforceable international law cannot of itself insure peace and freedom. But it is indispensable to the other necessary measures. ${ }^{109}$ Without the protection against aggression that their combined strength can secure,

the great Powers. That, as I see it, is nonsense. No one has more to gain from such unanimity than the smaller and middle-sized Powers. But what is the use of a unanimity which can be achieved only by doing nothing, which is used as a cloak for obstruction and reaction? That kind of unanimity is meaningless and will get us nowhere." General Assembly (5th Session) 302nd Plenary Meeting, Nov. 3, 1950.

107. Speech of M. Gutierrez, note 73 supra.

108. A clear statement of this dilemma appears in The United Nations Faces Aggression, an address by Ambassador Ernest Gross, reprinted in 24 DEP'T STATE Bulz. 57 (1951).

109. Eloquent statement of this indispensability was made by Sir Carl Berendsen before 
member states cannot be expected to cooperate freely and fully for the promotion of human rights, enlightenment, health, wealth and other values. If the vast majority of the United Nations can, however, effectively organize their strength against aggression, international law, instead of being made to await an "order" which never arrives, may perhaps be made an instrument for that integration of many measures which is an essential prerequisite to lasting peace.

the General Assembly. Official Record, Gen. Assembly, 280th Meeting, September 21, 1950, at p. 39:

"Peace and order cannot be preserved by words alone. Peace and order cannot be preserved without force, even in the most civilized communities in the world. Crime and disorder cannot be restrained in New York or in Washington or in London or in Ottawa, or even in Moscow, without force."

The theme is developed in McDougal, The Role of Law in World Politics, 20 Miss. L. J. 253 (1949). 


\title{
THE YALE LAW JOURNAL
}

\begin{tabular}{lll}
\hline VOLUME 60 & FEBRUARY, 1951 & NUMBER 2 \\
\hline
\end{tabular}

\author{
EDITORIAL BOARD \\ STUART W. THAYER \\ Editor-itr-Chief \\ WIILIANR R. PERLIK \\ Executive Editor
}

BERNARD H. GREENE

WIILIAMS DILL ROgERS

BURKe MarshalL Article and

Comment Editors

\section{Book Review Editor}

\author{
DANiet J. Freed \\ RICEARD N. GARDNER \\ ROBERT K. LIFTON \\ Note Editors
}

\section{WALTER G. FARR, JR. Case Editor}

CURTIS J. BERGER

Thomas F. Bergin

HARRY F. BRAUER

JOEL L. CARR

James C. Cochrane

Paut U. Daniet

HAROLD D. FIELD, JR.

ROBERT A. FleTCHER

STANLEy J. FrIEdMan

JoHN S. HofFINGER

JUNIUS HofrMaN

Marie McMahon

Business Secretary

Subscription price $\$ 5.50$ per year
Henry L. KING

Managing Editor

\begin{abstract}
ROBERT P. LYONS
HarRold J. McComas

Patricta A. McGowan

KURT W. MELCHIOR

Douglas S. Palamer

JERONIE H. REICH

Sherman G. Sass

EDWARD F. SNYDER

STEPHEN W. TULIN

HULEN D. WENDORF

JoAN ZeLDES

Richard A. ZUNIGA
\end{abstract}

Michaed J. Lichtenstein Student Business Manager

This number, $\$ 1.00$

Canadian subscription price $\$ 6.00$ per year; Foreign, $\$ 6.25$ per year for prices on other issues inquire

The Yale Law Journal Company, 401A Yale Station, New Haven, Connecticut

\section{CONTRIBUTORS TO THIS ISSUE}

Leo Gross, author of The Criminality of Aggressive War, 41 Aur. Pol. Scr. REv. 205 (1947), and other articles; PAzIfismus UND IMPerialismus (1931). Professor of Law, Fletcher School of Law and Diplomacy.

Myres S. McDougaL, B.A. 1926, M.A. 1927, LL.B. 1935, University of Mississippi; B.C.L. 1930, Oxford University; J.S.D. 1931, Yale University. Assistant General Counsel, Lend-Lease Administration, 1942; General Counsel, Office of Foreign Relief and Rehabilitation Operations, 1943. Member, Board of Editors, American Journal of International Law. William K. Townsend Professor of Law, Yale Law School.

RICHARD N. Gardner, B.A. 1948, Harvard University. Note Editor, Yale Law JourNaL. Rhodes Scholar-elect 1951-53. Third-year student, Yale Law School. 